\title{
Mineralization of orthanilic acid is a plasmid-associated trait in Alcaligenes sp. O-1
}

\author{
Michael Jahnke, ${ }^{*}$ Tarek El-Banna, $\dagger$ Rolf Klintworth and Georg Auling \\ Institut für Mikrobiologie der Universität Hannover, Schneiderberg 50, D-3000 Hannover, Federal Republic of Germany
}

(Received 17 May 1990; revised 11 July 1990; accepted 19 July 1990)

\begin{abstract}
A bacterial isolate (O-1) which degrades different substituted benzenesulphonates was identified as a strain of Alcaligenes sp. using chemotaxonomic, DNA:DNA hybridization and serological methods. Its ability to mineralize orthanilic acid (2-aminobenzenesulphonate) is correlated with the presence of a $117 \mathrm{MDa}$ plasmid, designated pSAH. Selective curing of pSAH resulted in the abolition of the orthanilic acid mineralization phenotype, which could be fully restored by re-establishment of pSAH. A second plasmid of 6.8 MDa, designated pME1702, with no detectable functions, is also present in Alcaligenes sp. O-1. Upon conjugation with Alcaligenes sp. O-1 as donor, the plasmid-free recipient Pseudomonas putida PaW130 acquired the ability to utilize orthanilic acid. Exconjugants of $P$. putida PaW130 harboured both plasmids (pSAH and pME1702) originating from Alcaligenes sp. O-1. Growth characteristics, the inducibility of enzyme activity (desulphonation), and expression of characteristic proteins during mineralization of orthanilic acid indicate that a plasmid-encoded cluster of genes is involved in the biodegradation of orthanilic acid. Southern blot hybridizations did not reveal any relationship between pSAH and the archetypal TOL plasmid pWW0, which also mediates degradation of substituted aromatic compounds.
\end{abstract}

\section{Introduction}

Sulphonated aromatic compounds are building blocks of detergents and azo dyestuffs. Introduction of sulphonic substituents improves the water solubility of aromatic compounds, but enhances their recalcitrance (Bretscher, 1981; Cook et al., 1986), so that aromatic sulphonates may accumulate in the environment (Leisinger, 1983). Although the biodegradability of these compounds has been reported by several laboratories, pure cultures which efficiently attack benzenesulphonates (Thurnheer et al., 1986; Zürrer et al., 1987; Locher et al., 1989) or naphthalenesulphonates (Brilon et al., 1981; Ohe \& Watanabe, 1988; Wittich et al., 1988) have only recently been isolated, using specific enrichment techniques.

Among a collection of 17 isolates which degraded benzenesulphonates, strain O-1, tentatively identified as a Pseudomonas sp. by a few criteria, was found to be the most versatile, degrading three different analogues

Abbreviations: $\% D$, degree of binding; PYE, peptone yeast extract; SSC, standard saline citrate; TBE, Tris/borate/EDTA; TE, Tris/EDTA.

$\dagger$ Present address: Microbiology Department, Faculty of Pharmacy Tanta University, Tanta, Egypt.
(Thurnheer et al., 1986). A large plasmid has been detected in this strain (Auling, 1986, Report on EMBO Fellowship no. ASTF 5111) and a plasmid-mediated biodegradative capacity was therefore suspected. Analogous examples of plasmid-mediated degradation of a diversity of aromatic pollutants are well documented (for a review see Frantz \& Chakrabarty, 1986).

We now report on the identification of isolate $\mathrm{O}-1$, and the contribution of a $117 \mathrm{MDa}$ plasmid to the biodegradation of orthanilic acid by this organism. Intra- and interspecies transmissibility of this plasmid was examined as was its relationship to the archetypal TOL plasmid, pWW0 (Williams \& Murray, 1974).

\section{Methods}

Bacterial strains and plasmids. These are listed in Table 1.

Media, culture conditions and analysis of substrate utilization. The mineral medium described by Thurnheer et al. (1986) was supplemented with either $6 \mathrm{~mm}$-orthanilic acid (MO) or $10 \mathrm{~mm}$-succinic acid (MS). The biodegradative strains were maintained under selective conditions (Alcaligenes sp. O-1 on MO agar; Pseudomonas putida PaW1 on $5 \mathrm{~mm}$ - $m$-toluate agar as described by Williams \& Murray, 1974). The complex medium (PYE) used in some experiments has been described by Busse \& Auling (1988). Antibiotics were added as indicated. Cultures were incubated at $30^{\circ} \mathrm{C}$ unless otherwise stated. 
Table 1. Bacterial strains and plasmids

\begin{tabular}{|c|c|c|c|}
\hline Strain & & Relevant characteristics & Source or reference \\
\hline \multicolumn{4}{|l|}{ Alcaligenes } \\
\hline faecalis & DSM $30030^{\mathrm{T}}$ & & $\begin{array}{l}\text { K. H. Hinz } \\
\text { Kersters \& De Ley (1984) }\end{array}$ \\
\hline piechaudii & NCTC $11970^{\top}$ & & $\begin{array}{l}\text { P. Kämpfer } \\
\text { Kiredjian et al. (1986) }\end{array}$ \\
\hline $\begin{array}{l}\text { xylosoxidans subsp. } \\
\text { denitrificans }\end{array}$ & NCTC $8582^{\mathrm{T}}$ & Formerly Alcaligenes denitrificans & $\begin{array}{l}\text { K. H. Hińz } \\
\text { Kersters \& De Ley (1984) }\end{array}$ \\
\hline $\begin{array}{l}\text { xylosoxidans subsp. } \\
\text { xylosoxidans }\end{array}$ & KM $534^{\mathrm{T}}$ & Formerly Achromobacter xylosoxidans & $\begin{array}{l}\text { K. H. Hinz } \\
\text { Kiredjian et al. (1986) }\end{array}$ \\
\hline $\begin{array}{l}\text { sp. } \\
\text { sp. }\end{array}$ & $\begin{array}{l}\text { O-1 } \\
\text { Cur30 }\end{array}$ & $\begin{array}{l}\text { pSAH, pME1702; degradation of benzenesulphonates } \\
\text { pSAH cured; pME1702; } \mathrm{Cm}^{\mathrm{R}}, \mathrm{Km}^{\mathrm{R}} ; \text { degradation-negative } \\
\text { derivative of strain } \mathrm{O}-1\end{array}$ & $\begin{array}{l}\text { Thurnheer et al. (1986) } \\
\text { This work }\end{array}$ \\
\hline \multicolumn{4}{|l|}{ 'Alcaligenes' } \\
\hline paradoxus & DSM $66^{\mathrm{T}}$ & & $\begin{array}{l}\text { DSM } \\
\text { Kersters \& De Ley (1984) }\end{array}$ \\
\hline eutrophus & DSM $531^{\mathrm{T}}$ & & $\begin{array}{l}\text { DSM } \\
\text { Kersters \& De Ley (1984) }\end{array}$ \\
\hline $\begin{array}{l}\text { Comamonas } \\
\text { acidovorans }\end{array}$ & DSM $39^{\mathrm{T}}$ & Formerly Pseudomonas acidovorans & $\begin{array}{l}\text { DSM } \\
\text { Tamaoka et al. (1987) }\end{array}$ \\
\hline \multicolumn{4}{|l|}{ Pseudomonas } \\
\hline putida & $\mathrm{mt}-2$ & Obtained as $\mathrm{PaW} 1$; pWW0; degradation of $m$-toluate & $\begin{array}{l}\text { P. A. Williams } \\
\text { Williams \& Murray (1974) }\end{array}$ \\
\hline putida & PaW130 & plasmid-free derivative of $P$. putida $\mathrm{PaW} 1$; Rif ${ }^{\mathrm{R}}$ & $\begin{array}{l}\text { P. A. Williams } \\
\text { Keil et al. }(1985)\end{array}$ \\
\hline putida & Ex5, Ex11 & $\begin{array}{l}\text { pSAH, pME1702; exconjugants of } P \text {. putida } \mathrm{PaW} 130 \text { following } \\
\text { matings with Alcaligenes sp. O-1 }\end{array}$ & This work \\
\hline $\begin{array}{l}\text { Escherichia } \\
\quad \text { coli }\end{array}$ & PM191 & $\begin{array}{l}\text { pWW0-3004, } 2 \cdot 25 \mathrm{~kb} X h o \mathrm{I} \text { fragment carrying } x y l E \text { from the } \\
\text { TOL plasmid pWW0 }\end{array}$ & $\begin{array}{l}\text { P. A. Williams } \\
\text { Chatfield \& Williams (1986) }\end{array}$ \\
\hline
\end{tabular}

Abbreviations: $\mathrm{Cm}$, chloramphenicol; $\mathrm{Km}$, kanamycin; Rif, rifampicin; R, resistance; $\mathrm{T}$, type strain; Strains denoted $\mathrm{K}$. H. Hinz were kindly provided by Dr. Hinz, Tierärztliche Hochschule, Hannover, FRG., those denoted P. A. Williams were from Dr. P. A. Williams, University College of North Wales, Bangor, Gwynedd, UK., and the strain denoted P. Kämpfer was from Dr. P. Kämpfer, Technische Universität Berlin, FRG. DSM, German Collection of Microorganisms and Cell Cultures Ltd., Braunschweig, FRG; NCTC, National Collection of Type Cultures (Central Public Health Laboratory), London, UK.

High-performance-liquid-chromatography (HPLC) of orthanilic acid was done with a Beckman apparatus (model 332) and an UV absorbance detector (model 160) according to Thurnheer et al. (1986). Absorbance was measured at $254 \mathrm{~nm}$.

Enzymes and chemicals. Orthanilic acid (97\%) was purchased from Fluka, as was formamide; restriction endonucleases were from BRL or Boehringer and were used in accordance with the manufacturer's specifications; agarose was from Pharmacia. All other chemicals were obtained from Merck and were of reagent grade or better.

Preparation of cell extracts and enzyme assay. In order to detect inducible proteins specific for degradation of orthanilic acid, cells grown in MS were used as a $10 \%(\mathrm{v} / \mathrm{v})$ inoculum for growth in MO. The inoculum was washed in saline at room temperature prior to resuspension in prewarmed MO. Biodegradation was carried out in a 10 litre fermenter at $30^{\circ} \mathrm{C}, 300$ r.p.m. and at an aeration rate of 3 litres $\min ^{-1}$. Samples of biomass were harvested $\left(10000 \mathrm{~g}, 10 \mathrm{~min}, 4^{\circ} \mathrm{C}\right)$ at different growth phases for determination of desulphonation activity (Thurnheer et al., 1986) and polyacrylamide gel electrophoresis (PAGE) of cellular proteins (Auling et al., 1986). For SDS-PAGE, $20 \mu \mathrm{l}$ samples of cell extracts were supplemented with $1 \mu 110 \%(\mathrm{w} / \mathrm{v})$ SDS and $1 \mu 12$-mercaptoethanol prior to heat denaturation $\left(100^{\circ} \mathrm{C}\right.$, $5 \mathrm{~min})$. Samples were analysed on an $8-15 \%(\mathrm{w} / \mathrm{v})$ polyacrylamide gradient gel. Reference molecular mass standards were purchased from Pharmacia.

Taxonomic methods. Biochemical features, identification and probability calculation (API 20NE) of isolate O-1 were examined according to the instructions of the manufacturer (api bioMerieux $\mathrm{GmbH}$, Nürtingen, FRG). Polyamines were prepared and analysed according to Busse \& Auling (1988). Chromatography of quinones, isolation of DNA, determination of the $G+C$ content and DNA : DNA hybridization followed procedures previously described (Auling et al., 1986). Prior to renaturation experiments at $61^{\circ} \mathrm{C}$ using a buffer containing $20 \%(\mathrm{v} / \mathrm{v})$ formamide (puriss. p.a.), the DNA concentration was determined according to Richards (1974). Preparation of antiAlcaligenes sp. O-1 serum raised in rabbits and agglutination tests were carried out essentially as described by Auling et al. (1978). For double immunodiffusion assays (Ouchterlony, 1949) small petri dishes $(5 \mathrm{~cm}$ in diameter) containing a $5 \mathrm{ml}$ layer of $1 \%(\mathrm{w} / \mathrm{v})$ agarose were incubated at $37^{\circ} \mathrm{C}$ in a humidity chamber. The precipitation lines were stained and visualized as described by Chase (1967).

Plasmid isolation, digestion and hybridization. For plasmid analysis, a modification of the method of Eckhardt (1978) was followed. Colonies grown on PYE were suspended in $20 \mu \mathrm{l} \mathrm{TBE}$ buffer (Maniatis et al., 1982 ) containing $20 \%(w / v)$ sucrose and $7 \%(w / v)$ Ficoll 400 . A solution 
(10 $\mu \mathrm{l})$ of lysozyme $\left(1 \mathrm{mg} \mathrm{m}^{-1}\right)$ and RNAase $\left(10 \mu \mathrm{g} \mathrm{ml}^{-1}\right)$ was added immediately before loading $10 \mu \mathrm{l}$ of this mixture into the wells of a horizontal $0.5 \%$ agarose gel, containing $0.5 \%$ SDS. Complete lysis was achieved by adding $10 \mu \mathrm{l}$ TBE containing $30 \%(\mathrm{v} / \mathrm{v})$ glycerine, $7 \%$ (w/v) SDS and $0.05 \%$ bromophenol blue. Electrophoresis was carried out at $20 \mathrm{~V}$ for $30 \mathrm{~min}$, then at $80 \mathrm{~V}$ for $3 \mathrm{~h}$.

For preparative isolation of plasmid DNA, the alkaline SDS lysis procedure of Kado \& Liu (1981), modified by Nies et al. (1987), was used routinely.

To prepare plasmid pSAH free of either contaminating chromosomal or pME1702 DNA the procedure of Wheatcroft \& Williams (1981) was basically followed. Cleared lysates obtained from $50 \mathrm{ml}$ freshly harvested cells (Nies et al., 1987) were subsequently ethanolprecipitated at $4{ }^{\circ} \mathrm{C}$ overnight (Maniatis et al., 1982), resuspended in TE buffer ( $10 \mathrm{~mm}$-Tris/HCl, $10 \mathrm{~mm}$-EDTA; $\mathrm{pH}$ 8), and finally concentrated (Centricon $\mathrm{C} 10$, Amicon) to approximately $500 \mu \mathrm{l}$. This plasmid solution was layered onto a preformed $16 \mathrm{ml}$ sucrose gradient (BaxterGabbard, 1972) followed by centrifugation at $100000 \mathrm{~g}$ and $20^{\circ} \mathrm{C}$ for $4 \mathrm{~h}$. Fractions $(0.5 \mathrm{ml})$ were collected and analysed by agarose gel electrophoresis. Fractions containing pure pSAH DNA were combined and concentrated by ethanol precipitation at $-20^{\circ} \mathrm{C}$.

Restriction fragments were either purified with a glassmilk solution (Geneclean Kit, Biol0l Inc.) or directly random primed-labelled with digoxigenine-dUTP (Boehringer) before use as probes in hybridizations (Southern, 1975) on nitrocellulose filters. Because of the high sensitivity of the technique only $1 \mu \mathrm{g}$ of digested DNA was submitted to electrophoresis $(0.8 \%, \mathrm{w} / \mathrm{v}$, agarose, $20 \mathrm{~V}, 16 \mathrm{~h})$. Hybridizations were done at $68^{\circ} \mathrm{C}$ following the manufacturer's protocol with SSC $(150 \mathrm{~mm}-\mathrm{NaCl}$ and $15 \mathrm{~mm}$-sodium citrate, $\mathrm{pH} 7.0)$ as the standard buffer. Hybridization stringency was calculated according to Meinkoth \& Wahl (1985); 0.1 $\times$ SSC was used for high-, and $0.6 \times$ SSC for lowstringency conditions.

Plasmid curing and bacterial conjugation. For plasmid curing experiments, cells were repeatedly subcultured in PYE at either 27, 37, or $42{ }^{\circ} \mathrm{C}$ according to Trevors (1986). Cultures were incubated at the corresponding temperature until the late exponential phase of growth, diluted tenfold and repeatedly re-incubated until this phase of growth was reached again. Samples were first spread on PYE agar followed by replica plating on MO agar for selection of mutants incapable of degrading orthanilic acid. Clones were purified and loss of mineralization capability was confirmed by HPLC of supernatants from liquid cultures.

For mating experiments, overnight cultures were mixed, spotted onto nitrocellulose filters $(0.2 \mu \mathrm{m}$ pore size; Sartorius) and finally placed on PYE agar. After an appropriate incubation period the cells were resuspended from the filters and plated onto selective medium.

Exconjugants from matings $(24 \mathrm{~h})$ with Alcaligenes sp. Cur30 as recipient were selected on $\mathrm{MO}$ supplemented with chloramphenicol and kanamycin (each $100 \mu \mathrm{g} \mathrm{ml}^{-1}$ ). Exconjugants from matings ( $72 \mathrm{~h}$ ) with $P$. putida $\mathrm{PaW} 130$ as recipient strain were selected on $\mathrm{MO}$ supplemented with $300 \mu \mathrm{g}$ rifampicin $\mathrm{ml}^{-1}$.

\section{Results}

\section{Identification of isolate $O-1$}

A two-step procedure for identification of xenobioticdegrading Gram-negative aerobic bacteria has been proposed (Busse et al., 1989). This involves rapid identification at the genus level by chemotaxonomic methods and subsequent allocation to a species by DNA :DNA hybridization and other methods.
When the quinone system of strain O-1 was analysed, only a ubiquinone with eight isoprenoid units in its side chain (Q-8) was detected. This finding excludes O-1 from species of the fluorescent pseudomonads (Oyaizu \& Komagata, 1983; Auling et al., 1986) and from the genus Acinetobacter, which both possess an ubiquinone Q-9 and are also well known for their biodegradation potential (Dagley, 1986). The presence of 2-hydroxyputrescine and putrescine as dominant polyamines in strain $\mathrm{O}-1$ suggests its affiliation to the beta subclass of the Proteobacteria (Busse \& Auling, 1988).

The multiple-test system API $20 \mathrm{NE}$ identified strain $\mathrm{O}-1$ as Alcaligenes denitrificans with a probability of $69.9 \%$. However, the taxonomic status of the genus Alcaligenes is controversial (De Ley et al., 1986; Busse \& Auling, 1991). In order to allocate strain O-1 either to species within the genus Alcaligenes as defined at present (Kiredjian et al., 1986) or to those which are phylogenetically distant even from the family Alcaligenaceae (De Ley et al., 1986), an antiserum was raised against this isolate. The antiserum obtained had a high titre $(>1: 1024)$ in the homologous reaction. In the heterologous reactions with type strains of the genus Alcaligenes, the following titres were obtained: Alcaligenes xylosoxidans subsp. xylosoxidans KM 534 (1:512), Alcaligenes xylosoxidans subsp. denitrificans NCTC $8582(1: 64)$, Alcaligenes faecalis DSM $30030(1: 8)$. Alcaligenes piechaudii NCTC $11970(<1: 8)$. In Ouchterlony double diffusion assays (Fig. $1 a, b$ ) strain $\mathrm{O}-1$ and Alcaligenes xylosoxidans subsp. xylosoxidans KM 534 displayed the highest crossreactivity (both three to five precipitation lines). With Alcaligenes xylosoxidans subsp. denitrificans NCTC 8582, two precipitation lines were visible. Partial serological relatedness, indicated by spur formations, was observed to Alcaligenes faecalis DSM 30030, 'Alcaligenes' eutrophus DSM 531 and Comamonas acidovorans DSM 39.

Similarity of strain O-1 with both reference strains of Alcaligenes xylosoxidans was also observed by PAGE of cellular proteins (data not shown). The $\mathrm{G}+\mathrm{C}$ content of $66.1 \mathrm{~mol} \%$, obtained by six determinations, is not contradictory to an allocation of strain O-1 to either of the two subspecies. DNA homology measurements using the initial renaturation rate method of De Ley et al. (1970) confirmed a relatively close relatedness of O-1 to both type strains, A. xylosoxidans subsp. xylosoxidans KM 534 and $A$. xylosoxidans subsp. denitrificans NCTC 8582 . The values obtained $(51 \% D$ to NCTC 8582 and $40 \% D$ to KM 534) did not allow the inclusion of strain $\mathrm{O}-1$ in either of the two subspecies.

\section{Plasmid analysis}

Two plasmids were detected in Alcaligenes sp. O-1. The molecular masses of the plasmids were estimated from 

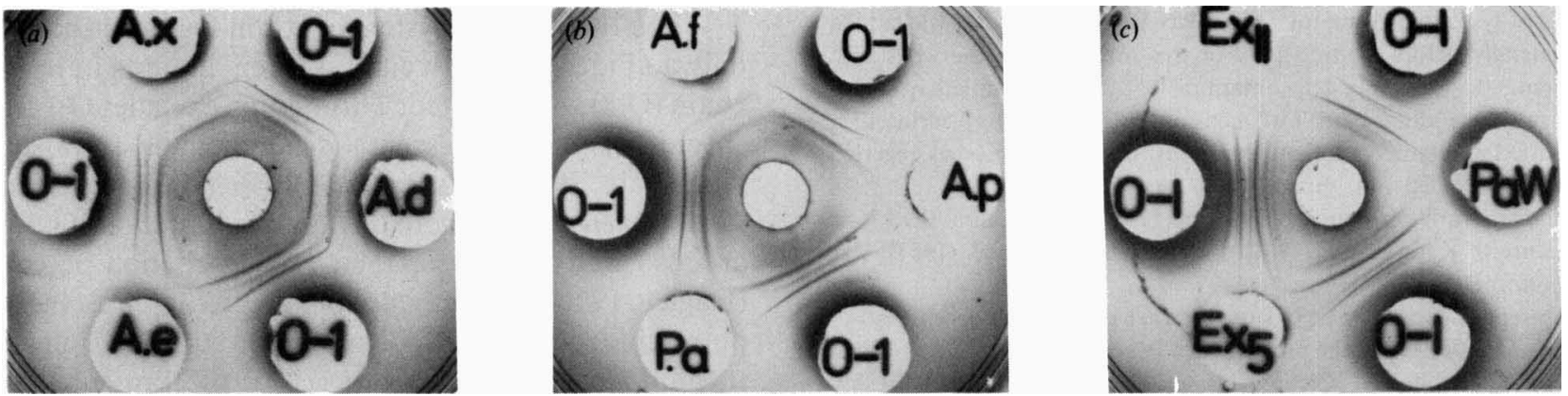

Fig. 1. Cross-reactivity of anti-Alcaligenes sp. O-1 serum with bacterial homogenates from related $(a)$ and phylogenetically less related (b) species from the beta-subclass of Proteobacteria, and from $P$. putida PaW130 exconjugants (c). The higher number of precipitation lines visible in $(c)$ is due to a more intensive staining procedure for detection of even weak cross-reactivity. Approximately $30 \mu \mathrm{g}$ protein of bacterial homogenates, prepared by ultrasonic treatment $(30000 \mathrm{~g}$ supernatants) were challenged with $30 \mu \mathrm{l}$ of anti-Alcaligenes sp. O1 serum (central well). Abbreviations: A.x, Alcaligenes xylosoxidans subsp. xylosoxidans KM 534 ${ }^{\mathrm{T}}$; A.d, Alcaligenes xylosoxidans subsp. denitrificans NCTC $8582^{\mathrm{T}}$, identical with DSM 30026; A.e, 'Alcaligenes' eutrophus DSM 531 ${ }^{\mathrm{T}}$; A.f, Alcaligenes faecalis DSM $30030^{\mathrm{T}}$; A.p. 'Alcaligenes' paradoxus DSM 66 ; P.a, Comamonas acidovorans (formerly Pseudomonas acidovorans) DSM 39'; PaW, recipient Pseudomonas putida $\mathrm{PaW} 130 ; \mathrm{Ex}_{5}, \mathrm{Ex}_{11}$, exconjugants $P$. putida Ex5 and P. putida Ex11; O-1, Alcaligenes sp. O-1, control for the homologous reaction (a superscript $\mathrm{T}$ denotes the type strain of the genus or species).
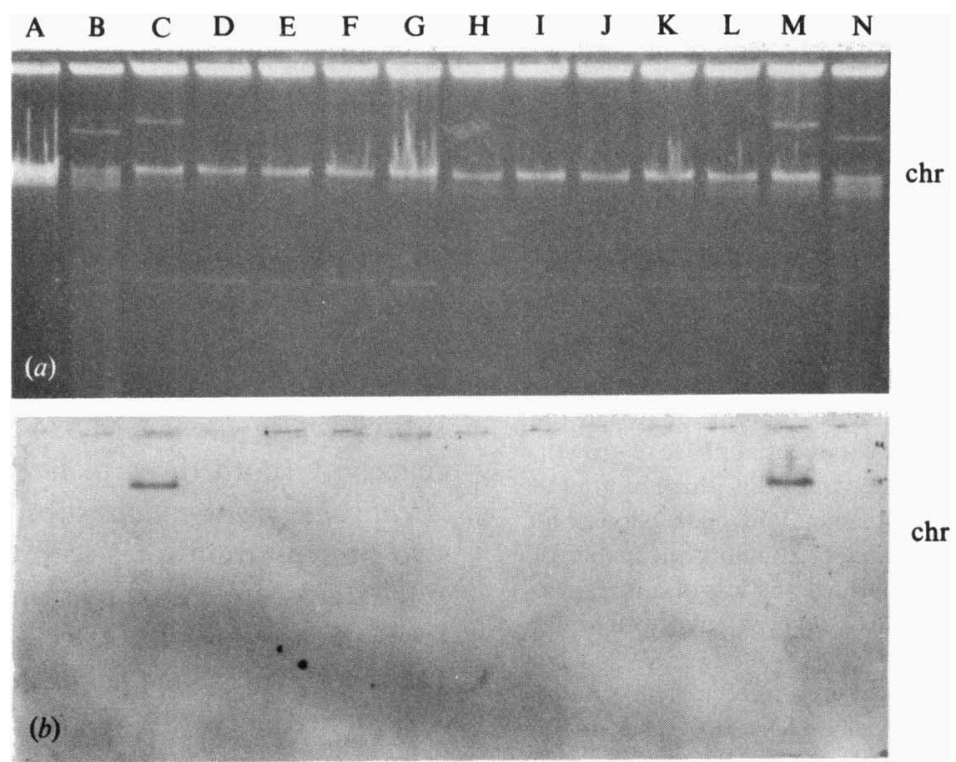

Fig. 2. Analysis of the plasmid content of Alcaligenes sp. O-1 and various 'cur' mutants. Following DNA gel electrophoresis (a), hybridization of the corresponding Southern blots $(b)$ with digoxigenine-dUTP-labelled pSAH DNA $\left(150 \mathrm{ng} \mathrm{ml}^{-1}\right)$ was carried out in $0 \cdot 1 \times$ SSC. Tracks contained: A, P. putida PaW130; B,N, P. putida mt-2; C, M, Alcaligenes sp. O-1 (positive control); D to L, different 'cur' mutants. chr, chromosomal DNA.

three independent electrophoresis runs with reference plasmids (Rochelle et al., 1985) as 117 and 6.8 MDa, respectively (data not shown). Restriction endonuclease digestion patterns (EcoRI) confirmed these estimations (see Fig. 4). The larger plasmid was designated pSAH (sulphoaromatics, $h$ igh molecular mass) and the smaller, at present under investigation in the Microbiology Institute of the ETH Zürich, Switzerland, designated pME1702 (T. Leisinger, personal communication).
Instability and conjugative transfer of the degradative activity

Alcaligenes sp. O-1 grows well at $30{ }^{\circ} \mathrm{C}$ (optimum temperature) with orthanilic acid as sole source of carbon and energy (Thurnheer et al., 1986). However, when cultures were incubated at $42{ }^{\circ} \mathrm{C}$ the ability to degrade orthanilic acid was completely lost within 20 generations. Clones which failed to degrade orthanilic 

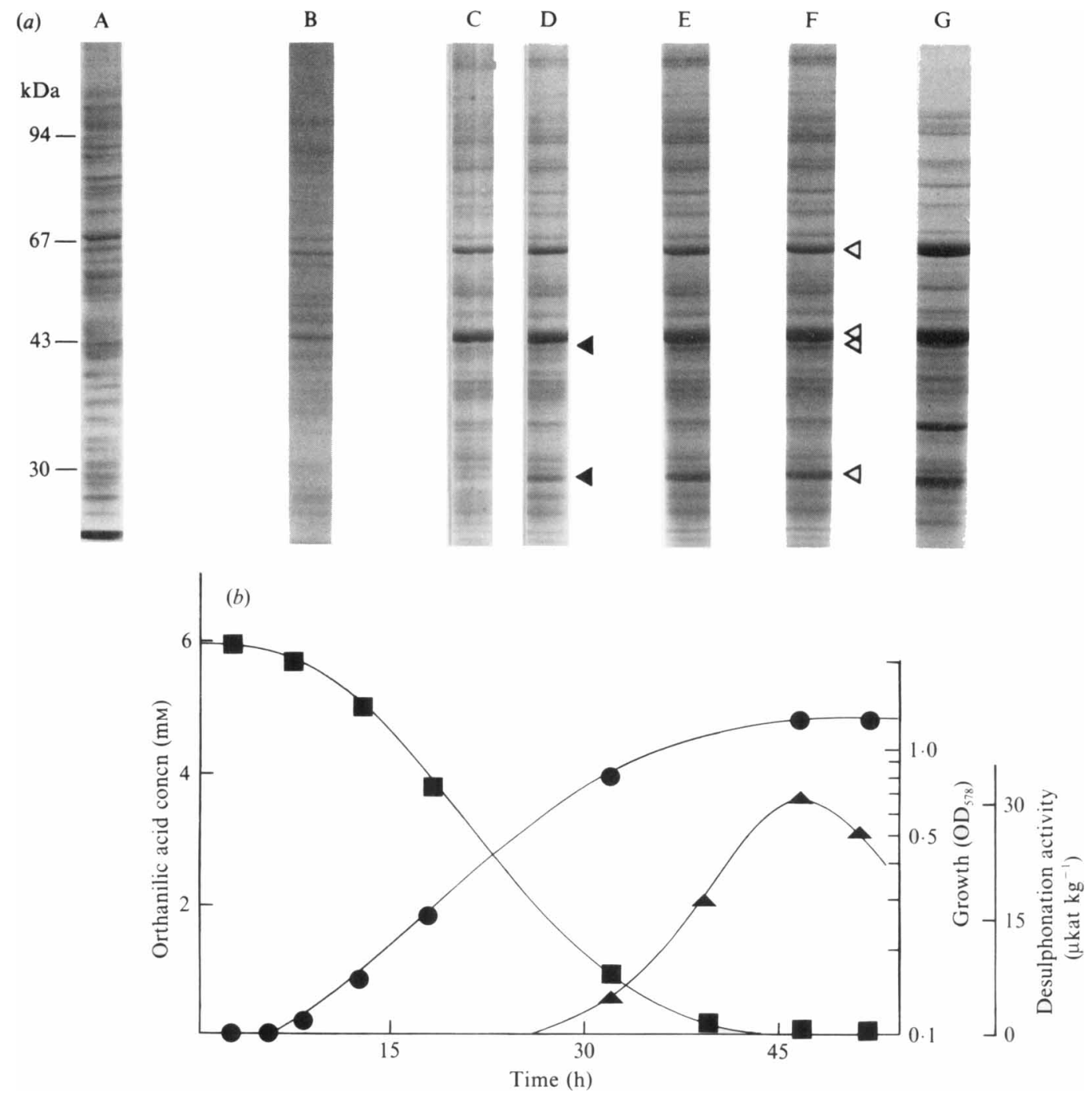

Fig. 3. Induction of specific polypeptides and desulphonation activity during growth of $P$. putida Ex 5 with orthanilic acid as sole carbon and energy source. (a) Protein patterns (SDS-PAGE) of the following cultures: A, MS inoculum culture, late exponential phase; B-F, growth with orthanilic acid after $12 \mathrm{~h}(\mathrm{~B}), 25 \mathrm{~h}(\mathrm{C}), 30 \mathrm{~h}$ (D), $40 \mathrm{~h}$ (E) and $50 \mathrm{~h}(\mathrm{~F}) ; \mathrm{G}$, Alcaligenes sp. O-1 after $50 \mathrm{~h}$ (control). The empty arrowheads $(\triangleleft)$ mark the four polypeptides which are distinctly induced during growth of $P$. putida Ex 5 on orthanilic acid. The two of these which appeared concomitantly with the desulphonation activity are marked with full arrowheads (4). (b) Growth (@), desulphonation activity $(\boldsymbol{\Delta})$ and orthanilic acid concentration $(\boldsymbol{G})$ during the above experiment.

acid were isolated and designated 'cur' mutants. At either $27^{\circ} \mathrm{C}$ or $37^{\circ} \mathrm{C}$, no loss of the biodegradative capability was observed within the equivalent experimentation period. However, upon prolonged cultivation (more than 50 generations) on rich medium (PYE) at $37^{\circ} \mathrm{C}$ spontaneous loss of the ability to grow on $\mathrm{MO}$ also occurred at a low $(0 \cdot 1 \%)$ rate (data not shown).

All of the 'cur' mutants analysed retained the small plasmid pME1702, but plasmid pSAH, present in the wild-type, was not detectable in any of them (Fig. 2). To exclude the possibility of integration of $\mathrm{pSAH}$ into the bacterial chromosome as a result of the curing treatment
(Sinclair et al., 1986) Southern hybridization analysis with pSAH as probe was carried out. Sequence homology to $\mathrm{pSAH}$ could not be detected within either chromosomal or pME1702 DNA in any of the 'cur' mutants (Fig. 2) although less than $0.05 \mathrm{pg}$ of homologous pSAH DNA was clearly detectable in control experiments following the specifications of the manufacturer.

The capability of Alcaligenes sp. O-1 to mineralize orthanilic acid is therefore strongly correlated with the presence of the large plasmid pSAH.

Intraspecies conjugation could be demonstrated between the donor Alcaligenes sp. O-1 and the recipient 


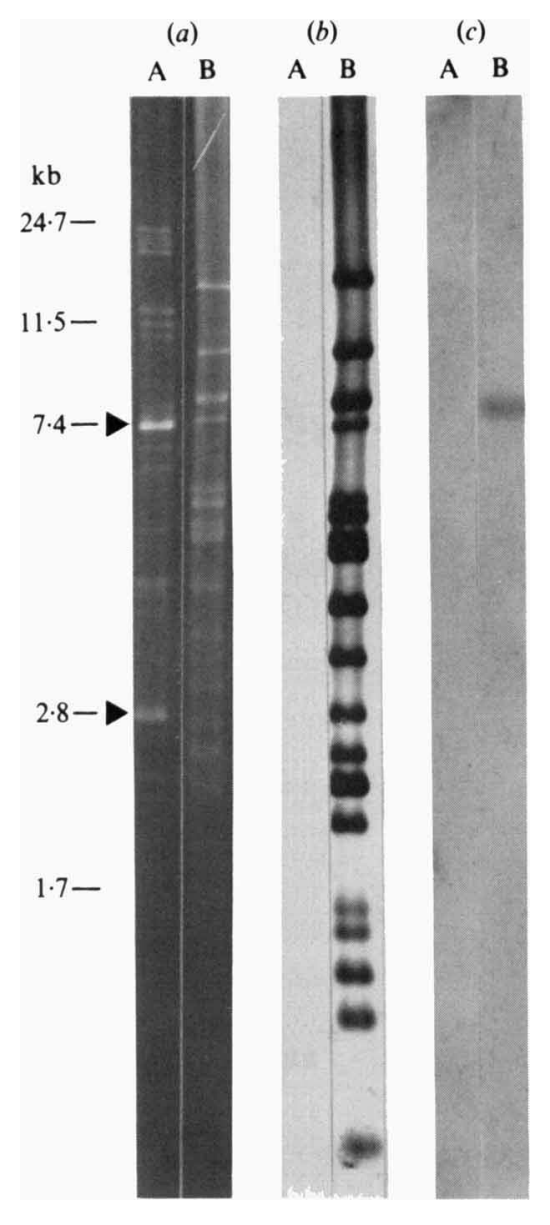

Fig. 4. Comparison of plasmids resident in Alcaligenes sp. O-1 with the archetypal TOL plasmid pWW0. (a) Agarose gel electrophoresis of restriction fragments $(E c o R I)$ of plasmids $\mathrm{pSAH}$ and pME1702 from Alcaligenes sp. O-1 (A) and plasmid pWW0 from P. putida $\mathrm{mt}-2$ (B). Fragments corresponding to pME1702 are arrowed $(\triangleright)$. Fragment sizes are given in $\mathrm{kb}$. Hybridizations were done either with fragments of plasmid pWW0, under stringent conditions (b), or with the PvuII restriction fragment of $x y l E$ (catechol 2,3-dioxygenase) from plasmid pWW0, under less stringent conditions (c). Digoxigenine-dUTPlabelled DNA $\left(100 \mathrm{ng} \mathrm{m}^{-1}\right.$ of $\mathrm{pWW} 0$ or $50 \mathrm{ng} \mathrm{ml}^{-1}$ of the $x y l E$ fragment) was used as probe.

Alcaligenes sp. Cur30. This 'cur' mutant regained the ability to grow on orthanilic acid concomitantly with the restoration of plasmid pSAH (not shown). No spontaneous mutation processes interfered with the observed frequency of conjugation (typically $1 \times 10^{-6}$ per donor). A coupled interspecies transfer of pSAH and pME1702 was observed between Alcaligenes sp. O-1 as donor and P. putida $\mathrm{PaW} 130$ as recipient (not shown). P. putida PaW130 exconjugants acquired the ability to grow on orthanilic acid with a typical conjugational frequency of $1 \times 10^{-6}$ per donor. If the donor strain Alcaligenes sp. O-1 was omitted from these matings, no biodegradative clones could be obtained.
Neither $P$. putida PaW130 nor the corresponding exconjugants cross-reacted with anti-Alcaligenes $\mathrm{sp}$. O-1 serum, either in agglutination $(<1: 8)$ or in Ouchterlony assays (Fig. 1c). The exconjugants had a polyamine pattern representative of the fluorescent pseudomonads (Busse \& Auling, 1988). Upon spraying with catechol the exconjugants, grown on orthanilic acid, formed a yellow compound representing 2-hydoxymuconic semialdehyde (Inouye et al., 1983). This test indicated that they had acquired a new catechol 2,3-dioxygenase activity upon conjugation because the plasmid-free recipient does not possess an equivalent enzyme activity (Keil et al., 1985). Polypeptides of identical molecular masses were specifically induced during growth on orthanilic acid in both the exconjugants and the donor Alcaligenes sp. O-1 (Fig. 3 ), namely two polypeptides of 61 and $45 \mathrm{kDa}$ in the early exponential and two more of 43 and $28 \mathrm{kDa}$ in the midexponential phase of growth. A fifth polypeptide of $34 \mathrm{kDa}$, present in strain $\mathrm{O}-1$, was only weakly induced in the exconjugant $P$. putida Ex5. The exconjugant displayed the highest activity of desulphonation in the late exponential phase of growth, as was observed for the donor Alcaligenes sp. O-1 by Thurnheer et al. (1986). The decline of desulphonation activity during the stationary phase of growth explains the extremely long lag phase observed with cultures of both donor and exconjugant after reinoculation from induced, but stationary-phase cells (Fig. 3).

\section{Comparison of pSAH with the archetypal TOL plasmid $p W W 0$}

The archetypal TOL plasmid pWW0 is the most extensively studied among the related (Lehrbach et al., 1983) degradative plasmids which mediate mineralization of substituted aromatic compounds (Burlage et al., 1989). In order to examine the possibility that pSAH has evolved from pWW0, the molecular relationship of the two plasmids was studied. With restriction fragments of total pWW0 as a probe no homology could be detected (Fig. $4 b$, A) under conditions of either high or low stringency in Southern blot hybridizations of plasmid DNA from Alcaligenes sp. O-1. Hybridization with the internal PvuII restriction fragment of pWW0-3004 (Chatfield \& Williams, 1986) which carries the TOLspecific $x y l E$ gene (catechol 2,3-dioxygenase), showed no homology either (Fig. 4c, A). However, a clear signal was found at the $7.8 \mathrm{~kb}$ position (fragment E, Burlage et al., 1989) of EcoRI-digested pWW0-DNA as expected (Fig. $4 c$, B). Hybridization of total DNA of Alcaligenes sp. O-1 with the same probe also revealed no signal (data not shown), indicating that no catechol 2,3-dioxygenase related to $x y l E$ is present in this strain. 


\section{Discussion}

The taxonomic methods applied placed isolate $\mathrm{O}-1$ in the neighbourhood of either Alcaligenes xylosoxidans subsp. denitrificans NCTC 8582 (formerly Alcaligenes denitrificans) or Alcaligenes xylosoxidans subsp. xylosoxidans KM 534 (formerly Achromobacter xylosoxidans). This has been confirmed by serological techniques and PAGE, both recommended as reliable taxonomic markers for Proteobacteria (Murray et al., 1990). According to the definition of Johnson (1984) the values obtained for DNA :DNA homology with the reference strains of the two subspecies $(51 \%$ and $40 \%)$ are too low to allow incorporation of isolate $\mathrm{O}-1$ in either of these taxa. Further studies including more strains would be necessary to establish a new species of Alcaligenes to accommodate isolate $\mathrm{O}-1$. As a consequence of this, and as the nomenclatural status of the genus Alcaligenes is still under dispute (Kersters and De Ley, 1984; De Ley et al., 1986; Kiredjian et al., 1986; Busse \& Auling, 1991), formal taxonomic proposals for a species designation for isolate $\mathrm{O}-1$ are avoided at present.

The large plasmid pSAH (117 MDa) present in Alcaligenes $\mathrm{sp}$. $\mathrm{O}-1$ is required for mineralization of orthanilic acid whereas the small plasmid pME1702 (6.8 MDa) remains cryptic. This was concluded from the observations that (i) curing of pSAH coincided with loss of the capacity to degrade orthanilic acid, and (ii) subsequent re-establishment of the original phenotype was achieved upon introduction of pSAH into the 'cur' mutant Alcaligenes sp. Cur30. Hybridization of total bacterial DNA with purified plasmid $\mathrm{pSAH}$ as a probe verified physical loss of plasmid pSAH in all 'cur' mutants derived from Alcaligenes sp. O-1. This observation excluded any integration of pSAH into the bacterial chromosome, a result often observed in curing experiments with other metabolic plasmids (Jeenes \& Williams, 1982; Meulien \& Broda, 1982; Eaton \& Timmis, 1986; Sinclair et al., 1986). The small plasmid pME1702 seemed to be rather stable, as no treatment (heat, ethidium bromide and acridine orange) of the 'cur' mutants resulted in plasmid-free derivatives, which was concluded from colony hybridizations of more than 2000 clones, using pME1702 as a probe (M. Jahnke, unpublished results).

With regard to the conjugative transfer of plasmids pSAH and pME1702 into P. putida PaW130 we assume that only the large plasmid pSAH is self-transmissible. Plasmid pME1702 may be mobilized passively because it seems to be too small to encode all the gene functions necessary for its own conjugative transfer. Plasmid pSAH possibly has a rather broad host range as it mediates gene transfer between Alcaligenes sp. and Pseudomonas putida, which belong to the beta and gamma subclasses, respectively, of the Proteobacteria (Stackebrandt et al., 1988).

Upon conjugative transfer of pSAH from Alcaligenes sp. O-1 into a foreign genetic background ( $P$. putida) no difference between donor and recipient was detected with regard to the expression of the orthanilic acid degradation phenotype. For example, growth rate, growth yield, retarded induction of both growth and specific polypeptides were identical (this paper; $M$. Jahnke, unpublished results). This indicates that a complete set of genes (both regulatory and structural) for transport and mineralization of orthanilic acid may be clustered on this large degradative plasmid. Strains free of plasmid pSAH neither grew on nor attacked orthanilic acid.

In order to estimate the number of degradative gene functions mediated by pSAH, Tn5 mutagenesis of Alcaligenes sp. O-1 is currently being done in our laboratory. Thus far it cannot be excluded that pSAH either mediates just the initial attack on the sulphonic substituents or provides only regulatory factors necessary for efficient degradation of orthanilic acid. Therefore it would be interesting to study expression of the orthanilic acid degradation phenotype upon conjugative transfer of pSAH into a recipient completely unable to mineralize aromatic compounds.

On the other hand, horizontal gene transfer has been discussed by Thurnheer et al. (1988) to explain results from experiments with a defined co-culture established for improved biodegradation of seven different sulphonated aromatic compounds. As Alcaligenes sp. O-1 was a member of this co-culture, we suspect that conjugative transfer of pSAH was involved in such events which resulted in strains of improved biodegradation capability. The calculated transfer frequencies for intra- and interspecies conjugation of pSAH were in the range reported for other catabolic plasmids, e.g. SAL (Chakrabarty, 1972), TOL (Williams \& Murray, 1974) and NAH (Dunn \& Gunsalus, 1973; Ferrer et al., 1986). These degradative plasmids of Pseudomonas spp. encoding the genes for the catechol meta-cleavage pathway (Frantz \& Chakrabarty, 1986) were all shown to be appreciably homologous with one another (Farrell \& Chakrabarty, 1979; Lehrbach et al., 1983). An evolutionary interrelationship of TOL ( $\mathrm{pWW} 0$ ) with the new degradative plasmid pSAH of Alcaligenes sp. O-1 was originally suspected. However, our results indicate no significant homology between these two plasmids (assuming a sufficient sensitivity of the non-radioactive technique applied). The heterogeneity of the genes encoding catechol 2,3-dioxygenase in pWW0 and pSAH indicates the presence of a new enzyme in Alcaligenes sp. O-1 because the meta-cleavage pathway is involved in the degradation of orthanilic acid (A. Cook, personal 
communication). This was concluded from the inhibition of ring cleavage by 3-chlorocatechol (Thurnheer et al., 1990). Recent results (Keil, 1990; Saint et al., 1990) imply that the structural gene for catechol 2,3-dioxygenase may have been evolved independently several times.

Although the degradative plasmids $\mathrm{pSAH}$ and $\mathrm{pWW} 0$ display no homology they may interact in a common host as both are conjugative. However, our preliminary data show that pSAH and pWW0 cannot coexist in Alcaligenes sp. $\mathrm{O}-1$, indicating that plasmid $\mathrm{pSAH}$ might belong to the IncP-9 group (Lehrbach et al., 1983). The recombination of catabolic genes resulting from conjugative interference of pSAH and pWW0 is under investigation in our laboratory, using both conventional and microcosm experiments.

The authors wish to thank T. Leisinger, A. M. Cook and T. Thurnheer for provision of strain $\mathrm{O}-1$, hospitality and many discussions. We are grateful to P. A. Williams for sending strains PaWI and $\mathrm{PaW} 130$, and the $x y / E$ gene probe. The help of K. Petzoldt and E. Müller in generation of the anti-Alcaligenes $\mathrm{sp}$. $0-1$ serum and of $\mathbf{M}$. Berg in preparation of the photographs is acknowledged. Support of F. Pilz in HPLC and J. Warrelmann in the analysis of large plasmids is appreciated. Strains Alcaligenes sp. O-1 and Alcaligenes sp. Cur30 will be deposited with the DSM.

This work was in part supported by a grant from the German Collection of Microorganisms and Cell Cultures (DSM, Braunschweig, FRG) to G.A.

\section{References}

Auling, G., Reh, M., Lee, C. M. \& Schlegel, H. G. (1978). Pseudomonas pseudoflava, a new species of hydrogen oxidizing bacteria: its differentiation from Pseudomonas flava and other yellow-pigmented, Gram-negative, hydrogen-oxidizing species. International Journal of Systematic Bacteriology 28, 82-95.

Auling, G., Probst, A. \& Kroppenstedt, R. M. (1986). Chemo- and molecular taxonomy of D(-)-tartrate-utilizing pseudomonads. Systematic and Applied Microbiology 8, 114-120.

BAXTER-GABBARD, K. L. (1972). A simple method for the large-scale preparation of sucrose gradients. FEBS Letters 20, 117-119.

BRETSCHER, $H$. (1981). Waste disposal in the chemical industry. In Microbial Degradation of Xenobiotics and Recalcitrant Compounds, pp. 65-74. Edited by T. Leisinger, A. M. Cook, R. Hütter \& J. Nüesch. London: Academic Press.

Brilon, C., BeCKMANN, W. \& K NACKMUSS, H.-J. (1981). Catabolism of naphthalenesulphonic acids by Pseudomonas sp. A3 and Pseudomonas sp. C22. Applied and Environmental Microbiology 42, 44-55.

Burlage, R. S., HoOper, S. W. \& SaYler, G. S. (1989). The TOL (pWW0) catabolic plasmid. Applied and Environmental Microbiology 55, $1323-1328$.

Busse, J. \& Auling, G. (1988). Polyamine pattern as a chemotaxonomic marker within the Proteobacteria. Systematic and Applied Microbiology 11, 1-8.

Busse, H.-J. \& AUling, G. (1991). The genus Alcaligenes (and 'Achromobacter'). In The Prokaryotes. A Handbook on the Biology of Bacteria. Ecophysiology, Isolation, Identification, Application, 2nd edn. Edited by A. Balows, H. G. Trüper, M. Dworkin, W. Harder \& K. H. Schleifer. New York: Springer-Verlag (in the Press).

Busse, H.-J., El-BanNa, T. \& Auling, G. (1989). Evaluation of different approaches for identification of xenobiotic-degrading pseudomonads. Applied and Environmental Microbiology 55, 15781583.
Chakrabarty, A. M. (1972). Genetic basis of the biodegradation of salicylate in Pseudomonas. Journal of Bacteriology 112, 815-823.

CHASE, W. (1967). Methods in Immunology and Immunchemistry, pp. 197-224. New York \& London: Academic Press.

Chatfield, L. K. \& Williams, P. A. (1986). Naturally occurring TOL plasmids in Pseudomonas strains carry either two homologous or two nonhomologous catechol 2,3-oxygenase genes. Journal of Bacterio$\log y 168,878-885$.

CoOK, A. M., Thurnheer, T., Kohler-Staub, D. \& Gälli, R. (1986). Mikrobieller Abbau von Xenobiotika. Swiss Biotech 4, 23-25.

DAGLEY, S. (1986). Biochemistry of aromatic hydrocarbon degradation in pseudomonads. In The Bacteria: a Treatise on Structure and Function, vol. 10, pp. 527-555. Edited by J. R. Sokatch \& L. N. Ornston. London: Academic Press.

De Ley, J., Cattolr, H., Reynaerts, A. (1970). The quantitative measurement of DNA-hybridization from renaturation rates. European Journal of Biochemistry 12, 133-142.

De Ley, J., Segers, P., Kersters, K., Mannheim, W. \& Lievens, A. (1986). Intra- and intergeneric similarities of the Bordetella ribosomal ribonucleic acid cistrons: proposal for a new family, Alcaligenaceae. International Journal of Systematic Bacteriology 36, 405-414.

DunN, N. W. \& Gunsalus, I. C. (1973). Transmissible plasmid coding early enzymes of naphthalene oxidation in Pseudomonas putida. Journal of Bacteriology 114, 974-979.

Eaton, R. W. \& Timmis, K. N. (1986). Spontaneous deletion of a 20kilobase DNA segment carrying genes specifying isopropylbenzene metabolism in Pseudomonas putida RE204. Journal of Bacteriology 168, 428-430.

ECKHARDT, T. (1978). A rapid method for the identification of plasmid deoxyribonucleic acid in bacteria. Plasmid 1, 584-588.

FarReLl, R. \& ChaKrabarty, A. M. (1979). Degradative plasmids: molecular nature and mode of evolution. In Plasmids of Medical, Environmental and Commercial Importance, pp. 97-109. Edited by K. N. Timmis \& A. Pühler. Amsterdam: Elsevier.

Ferrer, C., Cózar, E., Garcia-Valdés, E. \& Rotger, R. (1986). IncP-7 naphthalene-degradative plasmids from Pseudomonas putida. FEMS Microbiology Letters 36, 21-25.

FrantZ, B. \& ChakrabarTY, A. M. (1986). Degradative plasmids in pseudomonas. In The Bacteria : a Treatise on Structure and Function, vol. 10, pp. 295-323. Edited by J. R. Sokatch \& L. N. Ornston. London: Academic Press.

InOuYe, S., NaKazawa, A. \& NaKazawa, T. (1983). Molecular cloning of regulatory gene $x y l R$ and operator-promoter regions of the $x y l A B C$ and $x y l D E F G$ operons of the TOL plasmid. Journal of Bacteriology 155, 1192-1199.

JeENES, D. J. \& Williams, P. A. (1982). Excision and integration of degradative pathway genes from TOL plasmid $\mathrm{pWW} 0$. Journal of Bacteriology 150, 188-194.

JohNSON, J. L. (1984). Bacterial Classification. III. Nucleic acids in bacterial classification. In Bergey's Manual of Systematic Bacteriology, vol. 1, pp. 8-11. Edited by N. R. Krieg \& J. G. Holt. Baltimore: Williams \& Wilkins.

KADO, C. I. \& LIU, S.-T. (1981). Rapid procedure for detection and isolation of large and small plasmids. Journal of Bacteriology 145, 1365-1373.

KEIL, H. (1990). Molecular cloning and expression of a novel catechol 2,3-dioxygenase gene from the benzoate meta-cleavage pathway in Azotobacter vinelandii. Journal of General Microbiology 136, 607-613.

Keil, H., Keil, S., Pickup, R. W. \& Williams, P. A. (1985). Evolutionary conservation of genes coding for meta pathway enzymes within TOL plasmids $\mathrm{pWW} 0$ and $\mathrm{pWW} 53$. Journal of Bacteriology 164, 887-895.

Kersters, K. \& DE LeY, J. (1984). Genus Alcaligenes Castellani and Chalmers 1919. In Bergey's Manual of Systematic Bacteriology, vol. 1, pp. 361-373. Edited by N. R. Krieg \& J. G. Holt. Baltimore: Williams \& Wilkins.

Kiredjian, M., Holmes, B., Kersters, K., Guilvout, I. \& De LeY, J. (1986). Alcaligenes piechaudii, a new species from human clinical specimens and the environment. International Journal of Systematic Bacteriology 36, 282-287. 
Lehrbach, P. R., McGregor, I., Ward, J. M. \& Broda, P. (1983). Molecular relationships between Pseudomonas Inc P-9 degradative plasmids TOL, NAH, and SAL. Plasmid 10, 164-174.

LEISINGER, T. (1983). Microorganisms and xenobiotic compounds. Experientia 39, 1183-1191.

LOCHER, H. H., THURNHeER, T., LeIsinger, T. \& COOK, A. M. (1989). 3-Nitrobenzenesulfonate, 3-aminobenzenesulfonate, and 4-aminobenzenesulfonate as sole carbon sources for bacteria. Applied and Environmental Microbiology 55, 492-494.

Maniatis, T., Fritsch, E. F. \& Sambrook, J. (1982). Molecular Cloning, a Laboratory Manual. Cold Spring Harbor, NY: Cold Spring Harbor Laboratory.

Meinkoth, J. \& WaHL, G. (1985). Hybridization of nucleic acids immobilized on solid supports. Analytical Biochemistry 138, 267-284.

Meulien, P. \& Broda, P. (1982). Identification of chromosomally integrated TOL DNA in cured derivatives of Pseudomonas putida PAW1. Journal of Bacteriology 152, 911-914.

Murray, R. G. E., Brenner, D. J., Colwell, R. R., De Vos, P., Goodfellow, M., Grimont, P. A. D., Pfennig, N., StackeBRANDT, E. \& Zavarzin, G. A. (1990). Report of the ad hoc committee on approaches to taxonomy within the Proteobacteria. International Journal of Systematic Bacteriology 40, 213-215.

Nies, D., Mergeay, M., Friedrich, B. \& Schlegel, H. G. (1987). Cloning of plasmid genes encoding resistance to cadmium, zinc, and cobalt in Alcaligenes eutrophus CH34. Journal of Bacteriology 169, 4865-4868.

OHE T. \& WATANABE, Y. (1988). Microbial degradation of 1,6-naphthalenedisulfonic acid and 2,6-naphthalenedisulfonic acid by Pseudomonas sp. DS-1. Agricultural and Biological Chemistry 52, 2409-2414.

OUCHTERLONY, Ö. (1949). Antigen-antibody reaction in gels. Acta Pathologica et Microbiologica Scandinavica 26, 507-515.

Oyaizu, H. \& Komagata, K. (1983). Grouping of Pseudomonas species on the basis of cellular fatty acid composition and quinone system with special reference to the existence of 3-hydroxy fatty acids. Journal of General and Applied Microbiology 29, 17-40.

RichARDS, G. M. (1974). Modification of the diphenylamine reaction giving increased sensitivity and simplicity in the estimation of DNA. Analytical Biochemistry 57, 369-376.

Rochelle, P. A., Fry, J. C., Day, M. J. \& Bale, M. J. (1985). An accurate method for estimating sizes of small and large plasmids and DNA fragments by gel electrophoresis. Journal of General Microbiology 132, 53-59.

Saint, C. P., McClure, N. C. \& Venables, W. A. (1990). Physical map of the aromatic amine and $m$-toluate catabolic plasmid pTDN1 in Pseudomonas putida: location of a unique meta-cleavage pathway. Journal of General Microbiology 136, 615-625.

Sinclair, M. I., MaXwell, P. C., Lyon, B. R. \& Holloway, B. W. (1986). Chromosomal location of TOL plasmid DNA in Pseudomonas putida. Journal of Bacteriology 168, 1302-1308.

SOUTHERN, E. M. (1975). Detection of specific sequences among DNA fragments separated by gel electrophoresis. Journal of Molecular Biology 98, 503-517.

Stackebrand, E., Murray, R. G. E. \& Trüper, H. G. (1988). Proteobacteria, classis nov., a name for the phylogenetic taxon including the 'purple bacteria and their relatives'. International Journal of Systematic Bacteriology 38, 321-325.

TamaOKa, J., HA, D.-M. \& Komagata, K. (1987). Reclassification of Pseudomonas acidovorans den Dooren de Jong 1926 and Pseudomonas testosteroni comb. nov., with an emended description of the genus Comamonas. International Journal of Systematic Bacteriology 37, 5259.

Thurnheer, T., Köhler, T., CoOK, A. M. \& Leisinger, T. (1986). Orthanilic acid and analogues as carbon sources for bacteria: growth physiology and enzymic desulphonation. Journal of General Microbiology 132, 1215-1220.

Thurnheer, T., COOK, A. M. \& Leisinger, T. (1988). Co-culture of defined bacteria to degrade seven sulfonated aromatic compounds: efficiency, rates and phenotypic variations. Applied Microbiology and Biotechnology 29, 605-609.

ThURnheER, T., ZÜRRer, D., Höglinger, O., LeIsinger, T. \& COOK, A. M. (1990). Initial steps in the degradation of benzene sulfonic acid, 4-toluene sulfonic acid, and orthanilic acid in Alcaligenes sp. O-1. Biodegradation (in the Press).

TrEvors, J. T. (1986). Plasmid curing in bacteria. FEMS Microbiology Reviews 32, 149-157.

WheATCRoft, R. \& Williams, P. A. (1981). Rapid method for the study of both stable and unstable plasmids in Pseudomonas. Journal of General Microbiology 124, 433-437.

Williams, P. A. \& MurRaY, K. (1974). Metabolism of benzoate and the methylbenzoates by Pseudomonas putida (arvilla) $\mathrm{mt}-2$ : evidence for the existence of a TOL plasmid. Journal of Bacteriology 120, 416423.

Wirtich, R. M., Rast, H. G. \& KNaCKMUSS, H. J. (1988). Degradation of naphthalene-2,6- and naphthalene-1,6-disulfonic acid by Moraxella sp. Applied and Environmental Microbiology 54, 1842-1847.

ZÜRRER, D., COOK, A. M. \& LeISINGER, T. (1987). Microbial desulfonation of substituted naphthalenesulfonic acids and benzenesulfonic acids. Applied and Environmental Microbiology 53, 14591463. 